\title{
ANALISIS BERITA HOAKS DI ERA POST-TRUTH: SEBUAH REVIEW
}

\author{
ANALYSIS OF HOAX NEWS ON THE POST-TRUTH ERA: AN REVIEW
}

\author{
Cosmas Eko Suharyanto \\ Fakultas Teknik dan Komputer, Universitas Putera Batam, Batam \\ Jl. Let.Jend. Soeprapto, Mukakuning, Kota Batam \\ E-mail: cosmas@puterabatam.ac.id
}

Naskah diterima tanggal 14 September 2019, direvisi tanggal XX 2019, disetujui pada tanggal XX 2019

\begin{abstract}
This study aims to provide an initial analysis of how Indonesia in the post-truth era, nowdays becoming a world threat. Modern countries such as America and Britain can be ruined by post-truth storms, this is an alarm for the Indonesian people. The potential threats are of course different and in fact seen from the very diverse social situation of Indonesian people (ethnicity, religion, language, culture) the potential threats will be more dangerous if there is no good mitigation. Study literature the researchers use to provide a baseline analysis that occurs, to further deepen based on the current situation through the exploration of information from credible media. The pattern of hoaks news dissemination through social media received by the people of Indonesia and the results of surveys from various survey institutions give a clear picture that Indonesia is also not immune to the post-truth tsunami. The main medium of posttruth is alternative media, and post-truth is constrained if media literacy and fact-checking become a culture of community communication. The efforts made by the government, religious institutions, youth communities and online communities have helped to minimize the destructive effects of the post-truth era.
\end{abstract}

Keywords : hoax, social media, post-truth, instant messaging

\begin{abstract}
Abstrak
Penelitian ini bertujuan memberikan gambaran analisis awal bagaimana Indonesia di era post-truth yang sedang menjadi ancaman dunia. Negara yang maju seperti Amerika dan Inggis bisa porakporanda oleh badai post-truth, hal ini menjadi alarm bagi Bangsa Indonesia. Potensi ancaman tentu saja berbeda dan justru dilihat dari situasi sosial masyarakat Indonesia yang amat beragam (suku, agama, bahasa, kebudayaan) potensi ancaman akan lebih berbahaya jika tidak ada mitigasi yang baik. Studi literatur peneliti gunakan untuk memberikan pendasaran analisis yang terjadi, untuk selanjutnya melakukan pendalaman berdasarkan situasi terkini melalui penggalian telaah informasi dari media kredibel. Pola penyebaran berita hoaks melalui media sosial yang diterima masyarakat Indonesia dan hasil survei dari berbagai Lembaga survei memberi gambaran jelas bahwa Indonesia juga tak luput dari tsunami post-truth. Medium utama post-truth adalah media alternatif, dan post-truth mendapat hambatan jika literasi media dan fact-checking menjadi budaya komunikasi masyarakat. Upaya-upaya yang telah dilakukan pemerintah, Lembaga keagamaan, komunitas kepemudaan dan komunitas daring telah banyak membantu meminimalisir efek desktruktif era post-truth.
\end{abstract}

Kata Kunci : hoaks, media sosial, paska-kebenaran, pesan instan

\section{PENDAHULUAN}

Konvergensi teknologi komunikasi dan informasi berefek pada semakin beragamnya media komunikasi, mulai dari bentuk hingga aktivitas responsifnya. Dunia maya (cyberspace) telah memasuki babak baru. Cyberspace telah mengalihkan berbagai aktivitas manusia (politik, sosial, ekonomi, kultural, spiritual, seksual) di "dunia nyata"e ke dalam berbagai bentuk substitusi artifisialnya, sehingga apapun yang dapat dilakukan di dunia nyata kini dapat dilakukan dalam bentuk artifisialnya di dalam cyberspace (Pilliang, 2012). Teknologi Informasi telah merobohkan ruang, sekat waktu, tempat dan jarak menghantar pada era digital. 
Kemajuan Teknologi informasi yang begitu masif meluas ke semua bidang, juga memiliki efek negatif. Banjir informasi (information flood) di era revolusi digital menghadirkan sejumlah dampak sosial. Problem masyarakat bukan pada bagaimana mendapatkan berita, melainkan kurangnya kemampuan mencerna informasi yang benar. Kredibilitas media arus utama yang selalu digerogoti kepentingan elit dan pemilik, memaksa masyarakat mencari informasi alternatif (Syuhada, 2018). Kesenjangan antara kurangnya literasi media di tengah banjirnya informasi ini disalahgunakan oleh sebagaian kelompok untuk memproduksi berita yang tidak terkonfirmasi, yang belum tentu kebenarannya atau sering disebut hoaks. Media sosial menjadi medium penting penyebaran hoaks (Figueira \& Oliveira, 2017; Grech, 2017).

Dalam penelitian sebelumnya ditemukan fakta penting bagaimana pola komunikasi orang Indonesia saat ini. Skala besar penggunaan internet oleh orang Indonesia juga berkontribusi terhadap perubahan atau pengembangan partisipasi publik dalam kegiatan jurnalisme warga. Masyarakat lebih suka menggunakan media sosial seperti Twitter dalam menyampaikan berita / informasi mereka. Pergeseran ini juga disebabkan oleh fakta bahwa media massa, sebagai penyedia berita/informasi arus utama, telah dianggap sebagai partisan politik (Syahputra \& Ritonga, 2019). Keriuhan situasi media maya semakin mendapat siraman energi dalam tahun politik. Situasi ini dimanfaatkan oleh kelompok ataupun politisi untuk menggunakan segala cara demi tujuannya termasuk membuat dan menyebarkan kontenkonten bohong atau hoaks (Parani, Pramesuari, Maldiva, \& Felicia, 2018).

Fenomena hoaks yang masif menyebar menjadi konsumsi netizen setiap hari. Di satu sisi, banyak orang skeptis terhadap kredibilitas media massa. Namun, di sisi lain, hoaks menunjukkan, masyarakat justru mudah percaya pada beragam informasi media sosial (Amalliah, 2018). Masyarakat dikondisikan untuk mengabaikan verifikasi kebenaran. Kredibilitas berita, pesan, atau opini sering sudah tidak dipertanyakan lagi. Kebohongan menyelinap masuk melalui kebingungan orang dalam membedakan antara berita, opini, fakta, dan analisis (Haryatmoko, 2017).

Hoaks adalah anak kandung dari posttruth (Haryatmoko, 2017; Ulya, 2018). Posttruth digambarkan sebagai sebuah rentang masa yang cenderung mengabaikan fakta dan kebenaran sedangkan hoaks bisa diartikan sebagai berita atau informasi palsu/ bohong. Ken Willber, seorang "filsuf integral", dalam bukunya berjudul "Trump and the Post-truth World" (2017), post-truth dikaitkan dengan nihilisme, narsisme, skeptisime, dan postmodernisme, yang pada prinsipnya menolak kebenaran universal. Realitas dan kebenaran hanyalah persepsi atau terikat pada perspektif dan interpretasi individu. Juga, tidak ada kerangka moral dan kebajikan universal sebagai acuan bersama. Asumsi-asumsi filosofis itu menjadi dasar pijak operasi posttruth, baik dalam bentuk fake-news (berita bohong) maupun hoaks (berita fakta yang dipelintir) (Lusi, 2019).

Fenomena-fenomena yang terjadi di atas membangun konstruksi akan tujuan penelitian ini; untuk memberikan gambaran singkat tetapi menyeluruh tentang substansi penting bagaimana Indonesia menghadapai hoaks, media sosial, dan post-truth yang terpotret dari kajian ilmiah dan informasi kredibel dari media-media arus utama.

\section{TINJUAN PUSTAKA}

\section{Era Post-Truth}

Dilansir

media-media besar; Washington Post, BBC, Time, pada tahun 2016, Oxford Dictionaries, salah satu kamus daring terkemuka di dunia yang dibuat oleh Universitas Oxford, telah mentahbiskan 'post-

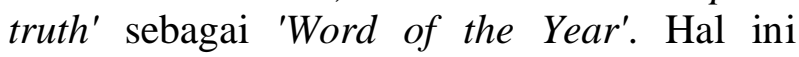
seharusnya tidak mengejutkan banyak orang, jika tahun 2016 menjadi tahun kejutan kontroversial dan peristiwa tak terduga. Panorama politik dan sosial selama beberapa waktu kedepan akan ditandai oleh iklim posttruth ini, di mana objektivitas dan rasionalitas memberi jalan kepada emosi, atau kesediaan untuk menjunjung tinggi kepercayaan 
meskipun fakta menunjukkan sebaliknya (LLORENTE \& CUENCA, 2017). Menurut Oxford Dictionaries, 'post-truth' diartikan sebagai istilah atau iklim yang berhubungan dengan atau mewakili situasi-situasi dimana keyakinan dan perasaan pribadi lebih berpengaruh dalam pembentukan opini publik dibanding fakta-fakta yang obyektif. Oxford Dictionaries juga menjelaskan bahwa terpilihnya 'post-truth' sebagai 'Word of The Year' karena dipengaruhi oleh cara kebanyakan orang masa kini untuk mendapatkan informasi. Mereka memilih menjadikan media sosial sebagai sumber berita. PEW Research Center pada tahun 2016 merilis bahwa 62 persen dari populasi Amerika akan menggunakan media sosial untuk tetap mendapatkan informasi terbaru (Gooch, 2017). Padahal, tidak semua hal yang ada di platform tersebut merupakan kebenaran. Internet telah mengubah cara orang berkomunikasi, tidak hanya dalam hal kecepatan, tetapi juga dengan memungkinkan individu untuk menemukan dan menyatu di sekitar kelompok lain dengan bias yang mirip dengan mereka sendiri, sehingga memperkuat keyakinan mereka.

\section{Tinjauan Etimologis Historis Post-Truth}

Istilah post-truth jika dicermati dari sisi etimologi, berasal dari kosakata Bahasa Inggris. Dalam Oxford Dictionary, disebutkan post artinya after (setelah) dan truth artinya quality or state of being true (kualitas atau dalam keadaan benar atau kebenaran) (Manser, 1996). Truth merupakan kata benda dari kata sifat true. Jadi post-truth artinya setelah atau paska-kebenaran. Kemudian disebut era posttruth atau era paska-kebenaran karena dalam rentang masa ini penggunaan akal yang melandasi kebenaran dan pengamatan fakta sebagai basis pengukuran obyektifitas seakanakan tak penting dalam mempengaruhi opini, pemikiran, maupun perilaku publik. Dalam rentang masa ini, orang mempengaruhi publik dengan cara menomorsatukan sensasionalitas dan menggerakkan emosionalitas (Haryatmoko, 2018). Publik lebih tertarik dengan kehebohan sebuah berita; begitu juga mereka lebih terpengaruh dengan barita dan hal-hal yang menyentuh perasaan, seperti membuat rasa gembira, melahirkan sikap sedih, kecewa, marah, dan seterusnya. Publik lebih sensitif jika disentuh sedikit emosinya.

Steve Tesich adalah orang pertama yang menggunakan istilah post-truth. Ia menggunakan istilah tersebut dalam artikelnya The Gorvernment of Lies di majalah The Nation yang terbit pada tanggal 6 Januari 1992. Ia mengambil latar belakang Skandal Watergate Amerika (1972-1974) maupun Perang Teluk Persia untuk menunjukkan situasi masyarakat pada saat itu yang tampaknya "nyaman" hidup dalam dunia yang penuh kebohongan (Tesich, 1992). Ia melihat bahwa masyarakat tidak terlalu peduli dengan sekelumit kebenaran yang ditegakkan dan dengan bebas memilih untuk hidup pada ruang post-truth.

\section{Konsep dan Karakteristik Post-Truth}

Jose Antonio Llorente, Kepala Lembaga kajian LLORENTE \& CUENCA (USA-Spain) dalam pengantar UNO Magazine berjudul "The Post-Truth Era: Reality vs Perception", mengatakan bahwa "Semua tonggak dari fenomena post-truth memiliki kesamaan: kepercayaan pribadi - yang bagi banyak orang tak terbantahkan — telah memperoleh kekuatan di hadapan logika dan fakta, dan telah menjadi mapan sebagai asumsi yang dibagikan oleh masyarakat, menyebabkan kebingungan dalam opini publik". Dalam iklim ini, cara-cara baru terkait dengan opini publik muncul dan media alternatif menjadi mapan. Metode jurnalisme tradisional kalah dengan munculnya saluran komunikasi baru seperti blog pribadi, YouTube, saluran pesan instan seperti WhatsApp, Telegram dan Facebook Chat, atau jaringan media sosial seperti Snapchat atau Twitter. Sebuah Tweet sederhana sekarang dapat memobilisasi massa dan memberikan efek yang tak terbayangkan bila dibandingkan beberapa tahun lalu. Penyebaran berita palsu menyebabkan kebohongan menjadi hal yang lumrah dan karenanya, muncul relativisasi kebenaran. Nilai atau kredibilitas media agak memudar dibandingkan dengan pendapat pribadi. Fakta-fakta itu sendiri menjadi nomor 
dua, sementara "bagaimana" sebuah cerita diceritakan lebih diutamakan daripada "apa" atau isinya. Karena itu, ini bukan tentang apa yang telah terjadi, melainkan tentang mendengarkan, melihat, dan membaca versi fakta yang lebih dekat dengan ideologi setiap orang (LLORENTE \& CUENCA, 2017).

Jose Antonio Zarzalegos, seorang jurnalis, mantan Direktur ABC dan El Correo, Spanyol, menegaskan bahwa post-truth tidak sinonim dengan kebohongan. Namun posttruth menggambarkan sebuah situasi dimana, ketika fakta-fakta obyektif kurang memiliki pengaruh dibandingkan dengan emosi dan kepercayaan pribadi.

Dr. Johanes Haryatmoko, S.J., dosen tetap Universitas Sanata Dharma, dan juga dosen terbang pascasarjana Universitas Indonesia, mengemukaan apa saja kebaruan dari post-truth. Era post-truth mendapat momentumnya karena massa jenuh dan membenci limpahan pesan dan rayuan: semua berujung meminta untuk membeli, mengonsumsi, memilih, memberi pendapat, atau ambil bagian di kehidupan sosial. Era post-truth mengutamakan bagaimana melihat dan membaca versi fakta yang lebih dekat dengan ideologi masing-masing. Lalu apa kebaruannya dibandingkan kebohongan yang sejak dulu sudah dipraktikkan dalam politik? Ada lima kebaruan yang menandai era posttruth: (1) luasnya akses ke konten informasi berkat digitalisasi komunikasi, (2) masyarakat bisa membuat informasi sendiri melalui medsos berkat demokratisasi media dan jurnalisme warga, (3) masyarakat lebih rentan menerima informasi yang keliru karena berkembang komunitas-komunitas se-ideologi, (4) teknologi telah merancukan kebenaran karena viral dianggap lebih penting daripada kualitas informasi dan etika, dan (5) kebenaran tidak perlu lagi difalsifikasi atau dibantah, tetapi kebenaran menjadi nomor dua. Kelima kebaruan itu memberi peluang politisi yang haus kekuasaan untuk merekayasa agar prasangka negatif kelompok-kelompok masyarakat diintensifkan melalui manipulasi emosi mereka.

Nayef Al-Rodhan, Kepala Program Geopolitik dan Global Futures di Pusat
Kebijakan Keamanan Jenewa, mengemukakan adanya kesamaan politik post-truth di berbagai negara. Post-truth menarik emosi dan lebih dari sekadar fakta dan bukti. Teori berita dan konspirasi palsu bisa menjadi viral dalam hitungan jam, menciptakan realitas alternatif dan melayani tujuan propaganda. Post-truth adalah ancaman bagi demokrasi (Al-Rodhan, 2017). Ia menambahkan geopolitik di era berita palsu juga rumit karena post-truth mengganggu elemen mendasar dari diplomasi dan politik internasional, yaitu komunikasi. Al Rodhan dalam Setiawan (2017) menyebutkan karakter-istik utama dari politik post truth adalah: (a) mengaduk-aduk masyarakat dengan hal-hal yang bersifat emosional, mengabaikan data dan fakta, mengutamakan dan mem-viral-kan berita yang belum tentu kebenarannya atau palsu, (d) mengkombinasikan gerakan populis dengan teori-teori konspirasi yang masih butuh diuji lagi kebenarannya, (e) mobilisasi narasi fiktif tentang figur atau peristiwa tertentu, dan (f) memoles ketidakjujuran dalam membangun opini untuk memperkuat posisi sosial figur, kelompok, atau kepentingan tertentu dalam masyarakat yang semakin terbiasa dalam peradaban televisual, online, android, dan media sosial (Setiawan, 2017).

\section{METODE}

Penelitian ini disusun dengan menggunakan metode penelitian deskriptif analitik di mana penulis mengambil dan memfokuskan perhatian pada permasalah yang menjadi pertanyaan penelitian. Hasil penelitian ini kemudian diolah dan dianalisis untuk pengampilan kesimpulan. Metode ini bertujuan untuk memperoleh pemaparan objektif atas sebuah masalah melalui proses analisis.

Selanjutnya penulis melakukan studi pustaka berupa pengamatan pada beberapa berita hoaks di media arus utama. Penelitian perpusatakaan sendiri merupakan kegiatan mengamati berbagai literatur yang berhubungan dengan pokok permasalahan yang diangkat baik itu berupa buku, jurnal, makalah ataupun tulisan yang sifatnya 
membantu sehingga dapat dijadikan sebagai pedoman dalam proses penelitian.

\section{PEMBAHASAN}

\section{Potret Post-Truth, Hoaks, dan Media Sosial}

Apa yang kita saksikan hari ini, di era post-truth lebih mengancam karena banyaknya saluran komunikasi. Informasi sekarang dapat beredar secara bebas dan tidak diverifikasi di Internet, memberikan kemungkinan kesalahan informasi dan propaganda pada skala yang sebelumnya hampir tidak mungkin terjadi. Akibatnya, sekarang mungkin untuk berbagi berita palsu lebih sering daripada berita yang diverifikasi, juga karena fakta bahwa media sosial telah memungkinkan proliferasi akun palsu yang tampak otentik atau menyesatkan yang membantu menyebarkan kebohongan, paling sering ditujukan kepada publik. Posttruth mewakili gelombang populisme berbahaya yang mengagungkan vulgaritas dan kebohongan, dengan implikasi yang tidak 'hanya' etis, tetapi mengganggu kestabilan politik domestik dan geopolitik.

Diawali dengan dua momen penting; riuhnya pilpres di Amerika melalui kemenangan Donald Trump, dan keluarnya Inggris Raya dari Uni Eropa (Brexit). Pada kedua momen itu, berita hoaks dengan sangat mudah disebarkan kepada masyarakat luas dan mempengaruhi opini publik.

Selama kampanye Trump ditengarai menggunakan fake news, antara lain menuduh Obama dan Hillary sebagai pendiri ISIS, adanya 30-an juta imigran ilegal dan deportasi massal, tingkat pengangguran Amerika 42\%, moderator debat capres tidak netral karena pendukung Partai Demokrat, dan masih banyak lagi. Setelah kebohongan dikonfirmasi dengan fakta, kubu Trump enteng menyebutnya sebagai bukan kebohongan, melainkan "alternative facts." New York Times membuat pernyataan bernada keluhan, "We have entered an age of post-truth politics." Sebuah studi dari PolitiFact menemukan $70 \%$ dari pernyataan-pernyataan Trump terkategori mostly false, false, dan untruth. Atas "prestasi" itu, Trump dianugrahi Lie of The Year 2015 dan 2017 (Lusi, 2019).
Pada kasus kedua, referendum Inggris Raya; Kampanye Referendum UE dipenuhi dengan klaim liar tentang Inggris, tetap bersama atau keluar. Baru-baru ini kandidat favorit Perdana Menteri (PM) Inggris Boris Johnson dipanggil Pengadilan London karena dituduh menyebarkan berita hoaks mengenai keharusan Inggris membayar GBP350 juta, jika Inggris tidak keluar dari Uni Eropa (UE). Berita hoaks itu yang menyiratkan Inggris harus keluar dari UE (Brexit) yang disebarluaskan melalui kampanye Johnson, ketika ia memulai cuti dari pekerjaannya jelang referendum Brexit, melansir dari Reuters (Akurat.com, 2019).

Di Ukrania, tumbangnya presiden mereka diawali dengan sebuah status di medsos yang dibuat seorang jurnalis di Facebook yang dilanjutkan dengan seruan berkumpul di Lapangan Maidan di Kiev. Di Mesir, medsos mengambil peran penting dalam penumbang-an Presiden Husni Mubarak, 2011. Sementara di Jerman, partai ultra-kanan mendapatkan $12,6 \%$ kursi di parlemen dengan cara menyebarkan ketakutan melalui medsos bahwa para pengungsi dari Suriah mendapat lebih banyak keuntungan daripada orang asli Jerman (Sulistyo, 2017).
Contoh potret
kasus-kasus gemilangnya post-truth di atas adalah sebagian dari sekian banyak yang bisa kita temukan di negara lainnya. Mengutip Victoria Prego, Presiden Madrid Press Asociation, bahwa penggandaan berita palsu adalah fakta yang secara serius mengancam kesehatan sistem demokrasi seperti yang kita ketahui sampai sekarang, di mana informasi profesional yang jujur serasa tidak berdaya. Dan sebenarnya, mereka tidak berdaya melawannya. Karena kebenaran yang tak terbantahkan adalah bahwa media tradisional telah kehilangan kredibilitas dengan mayoritas populasi. Kepercayaan yang pernah mereka tempatkan di media telah digantikan oleh keyakinan praktis yang tak terbatas pada informasi yang mereka terima melalui media sosial. Namun bias warga yang antusias dan menyerah terhadap cara baru berkomunikasi dan menerima informasi, dapat dipahami karena hal itu jauh dari para perantara yang, sampai 
sekarang, adalah surat kabar atau televisi. Warga negara sekarang adalah master dan penulis dari lingkungan informatif mereka sendiri (Prego, 2017).

\section{Indonesia dan Post-Truth}

Pola penyebaran berita hoaks melalui media sosial yang diterima masyarakat umumnya beragam jenis dan informasinya. Hasil penelitian Masyarakat Telematika (Mastel) tahun 2017 menunjukkan bahwa sebanyak 92,40 \% berita hoaks diterima masyarakat melalui sosial media seperti facebook, twitter, instagram serta path. Sementara sebanyak $62,80 \%$ diterima melalui aplikasi chatting seperti WhatsApp, Line, Telegram, dan sebanyak 34,90\% melalui situs web. Sementara jika dilihat dari jenis informasinya, peringkat pertama jenis hoaks yang diterima masyarakat terdiri dari sebanyak 91,80 \% berupa hoaks masalah sosial dan politik, baik itu terkait Pilkada ataupun tentang Pemerintah. Kedua, adalah masalah SARA sebanyak 88,60 \%, Kesehatan sebanyak 41,20 $\%$, makanan dan minuman sebanyak $32,60 \%$, penipuan keuangan sebanyak $24,50 \%$, Iptek sebanyak $23,70 \%$, sisanya adalah jenis hoaks seperti berita duka, candaan, bencana alam, serta lalu lintas (Mastel, 2017). Pola peningkatan diseminasi berita hoaks semakin meledak oleh kepentingan kekuasaan; Pilpres dan Pileg serentak 2019.

Menjelang beberapa hari sebelum pilpres dan pileg 2019 Kompas merilis artikel berjudul "Lunturnya Kearifan Berpolitik di Era Post-Truth". Artikel ini menggarisbawahi bahwa Indonesia juga tak luput dari badai post-truth yang dapat dirasakan dalam kontestasi lima tahunan ini. Kedua momen ini (Pilpres dan Pileg) kental diwarnai sifat-sifat destruktif: saling nyinyir, saling memfitnah, saling menghujat dan masih banyak lagi yang diniatkan untuk mendekonstruksi lawan demi meraih keuntungan politik. Politik di era posttruth, lebih banyak ditandai oleh para aktor dan simpatisan politik yang lebih mendahulukan perasaan dan emosi dibandingkan fakta objektif yang sesungguhnya. Termasuk pendapat grup afiliasi yang dianggap lebih benar bahkan dianggap "mutlak benar" daripada pendapat yang di luar kelompok afiliasinya. Hal ini semakin meruncing oleh adanya media sosial sebagai medium "sakti" era post-truth. Penguasaan informasi sebagai sebuah komoditas berharga saat ini konfigurasinya berubah total. Dulu, sebelum ada media sosial, kekuasaan atas informasi dipegang hanya pihak-pihak tertentu saja, yaitu pemerintah, elite, dan pers. Hadirnya media sosial nyaris membuat semua orang bisa menguasai dan menyebarkan informasi (Kompas, 2019).

Jika dilihat dari tahun-tahun sebelumya, rilis Kompas di atas tidaklah mengherankan. Dilansir Detik.com Sabtu, 26 Agustus 2017, Dirjen Aplikasi Informatika Kominfo Semuel Abrijani mengungkapkan bahwa sebanyak 6.000 situs internet telah diblokir. Situs-situs yang dblokir tersebut kebanyakan terkait penyebaran hoaks. Situasi ini mencapai "puncak" pada Pilpres dan Pileg 2019 yang lalu. Pemerintah "terpaksa" membatasi akses internet di seluruh Indonesia pada 22 Mei 2019 pasca pengumuman hasil Pilpres oleh KPU, dan berlanjut pada pemblokiran ribuan akun media sosial. Dalam keterangan tertulis (27/5/2019) Kominfo telah menutup dua ribuan akun medsos dan situs web sebelum dan selama pembatasan akses sebagian fitur platform medsos dan layanan pesan instan. Sebanyak 551 akun Facebook telah diblokir. Lalu 848 akun Twitter, Instagram dengan 640 akun, 143 akun YouTube, serta masing-masing 1 untuk url website dan LinkedIn. Dengan demikian total ada 2.184 akun dan website yang diblokir. Dalam pemblokiran ini, Kominfo pun bekerja sama dengan penyedia platform digital. "Itu juga ditempuh. Misalnya, saya telah berkomunikasi dengan pimpinan WhatsApp, yang hanya dalam seminggu sebelum kerusuhan 22 Mei lalu telah menutup sekitar 61.000 akun aplikasi WhatsApp yang melanggar aturan," jelas Menteri Komunikasi dan Informatika (Menkominfo) Rudiantara sebagaimana dilansir Detik.com, Senin sore 27 Mei 2019.

Kontestasi Pilkada DKI Jakarta 2017 antara Basuki Tjahaja Purnama dengan Anies Baswedan juga disinyalir sebagai bentuk 
fenomena post-truth. Dua calon berasal dari latar belakang etnis dan agama yang berbeda. Ujaran kebencian dan potongan-potongan informasi yang tak utuh dari beberapa peristiwa bertebaran bak hujan yang tak kunjung reda di dunia maya. Sepanjang kampanye Pilkada DKI Jakarta, media sosial dipenuhi ujaran kebencian, berita hoaks, dan informasi menyesatkan.

\section{Potensi Ancaman}

Negara yang maju seperti Amerika dan Inggis bisa porakporanda oleh badai posttruth, hal ini menjadi "alarm" bagi Bangsa Indonesia. Potensi ancaman tentu saja berbeda dan justru dilihat dari situasi sosial masyarakat Indonesia yang amat beragam (suku, agama, kebudayaan, bahasa, dll) potensi ancaman akan lebih berbahaya jika tidak ada mitigasi yang baik.

Warta Ekonomi (2018) menghadirkan data Kementerian Komunikasi dan Informatika (KemenKominfo) bahwa setiap harinya terdapat 3,3 juta informasi beredar di Facebook dan 29 juta informasi di WhatsApp. Dalam tsunami informasi itu, terdapat pula informasi hoaks karena Indonesia telah memasuki era post-truth (Wartaekonomi.co.id, 2018).

Salah satu ancaman sebagaimana digarisbawahi oleh Dr. Johanes Haryatmoko, S.J., adalah membangkitkan permusuhan (Haryatmoko, 2017). Manipulasi menyusup di celah-celah antara nilai, gagasan, dan opini sehingga ketiganya sulit dibedakan untuk akhirnya diterima sebagai fakta. Bentuk disinformasi ini mau menyentuh emosi masyarakat agar mudah membungkam pikiran kritis. Tujuannya: membangkitkan ketegangan dan permusuhan untuk mobilisasi massa. Jadi, disinformasi ini menjadi instrumen persuasi yang membidik empat hal: (1) bentuk rekayasa informasi agar orang bingung dalam menafsirkan realitas, (2) manajemen taktik konspirasi dengan membangkitkan kecurigaan dan permusuhan di antara kelompok-kelompok masyarakat, (3) menciptakan mitos-mitos politik, dan (4) self-fulfilling prophecy: pembenaran argumen politikus yang dikemas seperti ramalan, padahal sebetulnya peramal itu sekaligus aksekutornya.

Dengan merebaknya fenomena posttruth apabila tidak diantisipasi dengan mitigasi yang terencana dan terukur, juga akan berpotensi mempertajam polarisasi di masyarakat, ditandai dengan semakin viralnya pemberitaan yang tendensius mengusung sentimen agama, ras dan kelompok kepentingan yang dapat menjadi tantangan dan hambatan dalam memacu keberlanjutan pembangunan nasional, merawat NKRI. Kasus terbaru adalah kerusuhan di Papua, pemerintah melalui Kemkominfo kembali membatasi akses internet di Papua pasca kerusuhan yang terjadi di Papua Barat (21/8/2019). Kapolri Jenderal Tito Karnavian mengatakan aksi massa itu dipicu hoaks adanya korban meninggal akibat insiden di Surabaya (CNN Indonesia, 2019). Selain membahayakan bagi tatanan sosial kemasyarakatan, ancaman dapat mengarah pada disintegrasi bangsa.

Ancaman lain sebagai efek domino dari rusaknya sendi-sendi etika komunikasi masyarakat, adalah bagi keberlangsungan domokrasi sendiri. Narasi dominan zaman kita adalah bahwa demokrasi berada dalam keadaan darurat yang disebabkan oleh media sosial, perubahan jurnalisme, dan massa yang salah informasi. Krisis ini perlu diselesaikan dengan mengembalikan kebenaran di jantung demokrasi (Johan Farkas, 2019).

\section{Penegakan Hukum}

Penegakan hukum terkait kejahatan siber mengacu kepada Kitab Undang-Undang Hukum Pidana, Undang-Undang No 19 Tahun 2016 tentang Perubahan Undang-Undang No. 11 Tahun 2008 tentang Informasi dan Transaksi Elektronik (Indonesia, 2016), UU Nomor 40 Tahun 2008, tentang Penghapusan Diskriminasi Ras dan Etnis (Indonesia, 2008), UU Nomor 7 Tahun 2012 tentang Penanganan Konflik Sosial (Indonesia, 2012), dan Peraturan Kepala Kepolisian Negara Republik Indonesia Nomor 8 Tahun 2013 tentang Teknis Penanganan Konflik Sosial (Polri, 2013). Surat Edaran Kapolri Nomor SE/06/X/2015 soal Penanganan Ujaran Kebencian (hate speech) juga termasuk di 
dalamnya. Aspek ujaran kebencian yang diatur lewat SE itu meliputi ujaran yang bertujuan menghasut dan menyulut kebencian terhadap individu dan atau kelompok masyarakat dalam berbagai komunitas, yang terkait dengan perbedaan: suku, agama, aliran keagamaan, keyakinan atau kepercayaan, ras, antargolongan, warna kulit, etnis, gender, kaum difabel dan orientasi seksual (Kapolri, 2015).

Menko Polhukam Wiranto, sebagaimana diberitakan Detik.com pada Kamis, 28 Oktober 2018 memaparkan kasus serangan siber yang terjadi di Indonesia sepanjang 2018. Ada 324 kasus ujaran kebencian yang ditangani serta 53 kasus terkait hoaks (Detik.com, 2018).

Bagaimana dengan tahun 2019, dilansir Wartaekonomi.co.id, Kamis 27 Juni 2019, Kepala Biro Penerangan Masyarakat Divisi Humas Polri Brigadir Jenderal Polisi Dedi Prasetyo menjelaskan, jumlah penyebaran hoaks pada periode Januari hingga Desember 2018 mencapai 52 perkara. Namun sejak Januari hingga Juni 2019 jumlah penyebaran hoaks telah mencapai 51 kasus. Selain masalah penyebaran hoaks, pihaknya juga menangani tindak pidana ujaran kebencian. Pada tahun 2018, Polri menangani sebanyak 225 kasus, dengan penyelesaian kasus sebanyak 118. Sedangkan pada tahun 2019 sebanyak 101 kasus (Wartaekonomi.co.id, 2019).

Badai berita hoaks tak kunjung padam walaupun upaya penegakan hukum telah dijalankan. Diperlukan upaya-upaya pre-emtif, preventif untuk menekan laju gempuran berita hoaks.

\section{Potret Upaya Membendung Post-Truth}

Era ini juga ditandai banyak kaum muda yang menjadikan media sosial untuk memromosikan kekayaan budaya, produk lokal dan pesona alam daerah mereka masingmasing. Inisiatif-inisiatif yang tumbuh di wilayah lokal ini menandakan bahwa sebagai bagian tak terpisahkan dari proses globalisasi, kaum muda itu mampu memanfaatkan dan memaksimalkan peradaban android melalui media sosial untuk menyebarluaskan kekayaan alam dan dinamika budaya lokal yang masih eksis, selain keuntungan ekonomis.

Dampak positip pemenfaatan media sosial juga ditandai dengan berkembangnya marketplace yang mempertemukan penjual dan pembeli, e-comerce, UMKM yang memanfaatkan toko online, jasa transportasi online (Gojek, Grab, dll), rental mobil rumahan dan berkembangnya economic sharing resources sehingga semakin masifnya start-up bisnis, yang membuka peluang usaha baru, menciptakan pasar baru dan menggunakan sarana promosi baru yang efektif dan efesien berkat pemanfaatan positif media sosial.

Sangat disayangkan ketika budaya politik post-truth menjadi lebih dominan dan menggeser peran strategis media sosial. Diakui atau tidak, bangsa ini memang masih menyimpan banyak permasalahan yang bisa dikomodifikasi oleh individu atau kelompok tertentu untuk kemudian diledakkan melalui viral di media sosial. Persoalan SARA, misalnya, bisa setiap saat dimanfaatkan untuk "memobilisasi kecemasan dan ketakutan" komunitas tertentu apabila individu atau kelompok yang berbeda dalam hal agama atau suku berkuasa (Setiawan, 2017).

Banyak cara telah dilakukan untuk membendung badai hoaks dalam era posttruth ini. Upaya dilakukan baik dari sisi penyedia layanan (platform), pemerintah, maupun inisatif-inisiatif Lembaga-lembaga non pemerintah (keagamaan, ormas, akademisi, dll).

\section{1) Sisi Platform}

Bila kita cermati ketika kita membuat akun media sosial (facebook, Instagram, Whatsapp, dll) selalu ada "kebijakan" atau Policy yang harus kita pahami. Umumnya kebijakan penyedia layanan terkait umur, konten, identitas, dan kebijakan pelanggaran.

Jaringan media sosial terbesar di dunia, Facebook sebelumnya mendapat kecaman atas tuduhan bahwa pihaknya telah gagal memantau konten yang dibagikan dengan benar di platform itu, terutama pada pemilihan presiden AS tahun 2016. Untuk membersihkan namanya dari tudingan tersebut, CEO 
Facebook Mark Zuckerberg mengambil langkah melindungi kegiatan Pemilu dari berbagai kemungkinan kecurangan dan eksploitasi platform-nya. Melalui keterangan yang dilansir Liputan6.com (4 April 2018), VP of Product Management Facebook Guy Rosen, melakukan langkah-langkah untuk melindungi pengguna terkait hoaks, terutama saat Pemilu. Pertama adalah memberantas campur tangan pihak asing, selanjutnya, Facebook juga berupaya menghapus akun-akun palsu yang tersebar di platform tersebut. Ketiga, Facebook meningkatkan transparansi iklan dan keempat, Facebook terus mengurangi maraknya penyebaran berita palsu alias hoaks (Liputan6.com, 2018).

\section{2) Sisi Media Berita Online (arus utama)}

Diawali dari Dewan Pers telah melakukan verifikasi perusahaan pers. Ketua Dewan Pers Yosep Adi Prasetyo (Kompas.com 06/02/2017) mengatakan, verifikasi ini merupakan amanat UU No 40 Tahun 1999 tentang Pers untuk mendata perusahaan pers. Melalui verifikasi ini, Dewan Pers juga memastikan komitmen pengelola media dalam menegakkan profesionalitas dan perlindungan terhadap wartawan. Selain itu, melalui pendataan atau verifikasi perusahaan pers, Dewan Pers ingin mendorong penguatan media pers dan positioning media mainstream dalam memasuki era konvergensi media. Yosep mengatakan, media arus utama harus bisa mengembalikan kepercayaan publik dengan menjawab tantangan atas maraknya serbuan berita hoaks atau informasi bohong yang dibuat seolah-olah sebagai karya jurnalistik (Kompas.com, 2017).

Beberapa media besar tanah air secara resmi tersertifikasi dalam jaringan internasional penguji fakta (IFCN International Fact-Checking Network), diantaranya Kompas.com, Liputan6.com, Tirto, Media Indonesia, Tempo.co, Republika, dan beberapa media lainnya. Sebagaimana dimuat di Kompas.com (17/10/2018), Pemimpin Redaksi Kompas.com Wisnu Nugroho mengatakan bahwa Di era digital saat ini, masyarakat dihadapkan pada banjir informasi yang serba tidak pasti kebenarannya.
Sertifikasi IFCN ini meneguhkan komitmen Kompas.com yang selalu menguji setiap informasi untuk mencari dan menemukan kebenaran. Dengan upaya ini, hoaks yang marak dan menyamar sebagai informasi bisa dilawan.

\section{3) Sisi Pemerintah}

Sebagaimana dipaparkan pada paragraph-paragraf sebelumnya, terutama produk hukum, pemerintah telah berupaya menangkal hoaks. Dikutip dari CNN Indonesia, 23 Juni 2018, pemerintah mulai menggunakan teknologi kecerdasan buatan bernama Cyber Drone 9 untuk melacak dan melaporkan situs-situs yang diketahui mempublikasikan berita palsu. Pemerintah menerapkan sistem pemblokiran untuk menertibkan situs dan akun di media sosial yang menyebarkan berita palsu (CNN Indonesia, 2018). Masih dari CNN, Menurut laporan yang dirilis SAFEnet, sejumlah perusahaan media seperti Google dan Facebook juga digaet oleh pemerintah untuk membantu mengatasi penyebaran konten berbahaya, termasuk pornografi dan hoaks.

Melalui kementerian Komunikasi dan Informatika (Kemkominfo), pemerintah menyelenggarakan program ISAN (Internet Sehat dan Aman). Program INSAN diselenggarakan dalambentuk sosialisasi, roadshow dan forum diskusi dengan melibatkan seluruh komponen masyarakat.

Dalam rangka meminimalisasi persebaran konten-konten berita palsu di media sosial, Kementerian Komunikasi dan Informatika membuka situs aduan yang dapat diakses di laman : https://aduankonten.id. Situs ini merupakan fasilitas pengaduan konten negatif baik berupa situs/website, URL, akun media sosial, aplikasi mobile, dan software yang memenuhi kriteria sebagai informasi dan/atau Dokumen Elektronik bermuatan negatif sesuai peraturan perundangundangan.

Ribuan situs yang telah diblokir belakangan ini apakah merupakan kinerja dari berbagai tool yang telah pemerintah fungsikan, belum ada laporan yang bisa diakses publik 
yang membahas kinerja Cyber Drone 9, aduan konten ataupun tool lainnya.

\section{4) Inisiatif Komunitas}

Komunitas non pemerintah juga telah berinisiatif membendung laju hoaks, baik Lembaga keagamaan, akademi, maupun organisasi kepemudaan.

Gereja Katolik (KWI) melalui Komisi Komunikasi dan Sosial (Komsos) bekerjasama dengan KemKominfo telah melakukan upaya melalui literasi media (Mirificanews, 2018). Tak terhitung juga paroki-paroki yang berinsiatif menyelenggarakan animasi-animasi terkait hoaks. Kesadaran untuk cerdas di era teknologi juga selalu diperingati melalui Pekan Komunikasi Sosial. Pimpinan Gereja Katolik Universal, Paus Fransiskus juga telah banyak mengeluarkan himbauan terkait penggunaan media sosial (Catholic Herald, 2018).

Dilansir Jawapos.com (19/11/2017)

Pengurus Besar Nahdlatul Ulama (PBNU) membuat gebrakan di era digital saat ini. Ormas Islam terbesar yang dipimpin KH. Said Aqil Siroj itu meluncurkan sejumlah produk digital untuk merespons perkembangan zaman. Produk tersebut di antaranya, Aplikasi Mobile NU, Telivisi NU Channel, Data Center, Arab Pegon, dan Mobil Halal Investigasi (Jawapos, 2017). Dalam rangka menyebarkan berita baik dan menetralisir konten-konten negatif seperti hoaks, salah satu gebrakan PBNU adalah meluncurkan NU Channel melalui NIN media yang merupakan satelit TV tidak berbayar pertama dan satu-satunya saat ini (Beritasatu, 2018). Ormas otonom NU, GP Ansor juga membentuk Unit Khusus Cyber Anti Hoaks dengan nama Ansor Banser Cyber.

Walubi (Wali Umat Budha Indonesia) bekerjasama dengan pemerintah melalui Kementerian Komunikasi dan Informatika (Kemkominfo) Republik Indonesia mengadakan talkshow dan literasi sosial media bertajuk Bincang Digital (BiDig) Tangkal Hoaks (Makassar, 2018).

Komunitas daring Masyarakat Anti Fitnah Indonesia (Mafindo) menjadi terobosan baru keterlibatan kaum milenial melawan hoaks. Mafindo didirikan sebagai organisasi pada 19 November 2016, telah mempelopori banyak inisiatif anti hoaks, seperti crowdsourced hoaks busting, edukasi literasi digital untuk publik, CekFakta.com, dan kampanye publik untuk meningkatkan kesadaran tentang hoaks dan bahayanya (Mafindo, 2016).

Masih banyak lagi organisasi yang terus berinisiatif memerangi konten-konten negatif internet.

\section{PENUTUP}

\section{Simpulan}

Indonesia, sebuah negara dengan jumlah pengguna internet rangking lima dunia atau lebih dari 171 juta pengguna (65\%), tak bisa dipungkiri menjadi bagian dari masyarakat digital global dengan segala konsekwensi ancamannya.

Berubahnya pola dan perilaku masyarakat Indonesia dalam mendapatkan informasi, tak dapat dinafikan adalah efek dari hadirnya media alternatif. Bebarengan dengan masifnya penggunaan media alternatif, khususnya media sosial, aplikasi pesan instan, kondisi politik tanah air semakin menjadikan tanah digital Indonesia semakin subur ditumbuhi informasi yang menyesatkan atau hoaks.

Banyak upaya yang telah dilakukan baik oleh pemerintah, ataupun inisiatif lembaga-lembaga non-pemerintah, maupun komunitas daring. Namun, badai post-truth membutuhkan lebih banyak upaya lagi oleh lemahnya literasi media masyarakat dan kompleksnya masalah-masalah lain terutama politik identitas.

Post-truth tumbuh subur di lingkungan yang sangat terpolarisasi atau partisan, di mana gagasan kebenaran sudah dibagi menjadi gagasan "kebenaran saya vs kebenaran Anda". Berita hoaks kemudian memperkuat polarisasi politik dan sosial yang ada, yang mengarah lebih banyak perpecahan dan ketidakpastian. Singkatnya, dalam menghadapi kebisingan media yang berlebihan dan kurangnya kepercayaan, kita bisa belajar menjadi pemandu yang lebih baik dan membiarkan diri kita dibimbing. Mengambil kesempatan positif di era digitalisasi, untuk menyalurkan kecerdasan kolektif kita, sehingga 
menghindari penyimpangan menuju pengingkaran kebenaran kolektif.

\section{Saran}

Diubutuhkan sinergi seluruh komponen bangsa untuk melawan tsunami era post-truth dengan seabrek efek negatifnya. Berikut ini beberapa masukan upaya yang bisa dilakukan:

Literasi media digital adalah upaya preventif-edukatif untuk memberikan bekal kepada masyarakat ketika berinteraksi dengan media digital. Literasi digital menjadi suatu keniscayaan dalam melawan fenomena post truth yang ditandai dengan maraknya hoaks, false news maupun fake news, melalui literasi digital akan terbangun kemampuan untuk mengenali, memahami, menerjemah, mencipta, dan berkomunikasi dengan medium cetak, audio-visual, dengan mengedapankan nilai-nilai integritas, empati dan spirit membangun sinergitas saling menghargai. Literasi digital akan mendorong masyarakat untuk berpikir kritis (critical thinking), yaitu kemampuan untuk membedakan antara informasi nyata dan bohong, konten baik dan berbahaya, dan kontak online yang dapat dipercaya maupun yang diragukan. Literasi Media dapat dilakukan oleh siapa saja dan kepada objek siapa saja, baik komunitas, anak sekolah, mahasiswa, dan masyarakat luas lainnya. Bentuk Literasi Media juga bisa dilakukan dengan berbagai cara baik melalui media online, audi-visual, pelatihan teknis bermedia sosial sehat dan seminar, dan kegiatan lainnya.

Fact-Checking adalah tindakan memeriksa pernyataan faktual dalam teks nonfiksi untuk menentukan keakuratan dan kebenaran pernyataan faktual dalam teks. Sebagian besar situs-situs portal berita nasional Indonesia juga telah menyediakan layanan Fact-Checking dan tergabung dalam IFCN - International Fact-Checking Network.

Post-truth lebih tepat disebut lawan kata dari fact-checking: relativisasi kebenaran berhadapan obyektivitas data. Lalu terjadi banalisasi data karena adanya supremasi wacana emosional (Zarzalejos, 2017). Masih menurut Zarzalejos, bahwa mulai sekarang, komunikasi baru dan jurnalisme baru tidak akan banyak berfokus pada bercerita, tetapi lebih pada verifikasi. Ini karena yang pertama sudah bisa dilakukan oleh masyarakat sendiri menggunakan pilihan luas teknologi yang tersedia, sedangkan yang terakhir tidak bisa dilakukan oleh mereka.

Dari sisi media, masih beberapa media besar yang telah memiliki kanal FactChecking, hal ini harus menjadi perhatian pers untuk masuk dalam regulasi. Selain itu harus ada channel bersama yang terdiri dari komunitas anti-hoaks, pemerintah maupun dari pers membentuk kanal Fact-Checking sebagaimana Amerika memiliki PoliFact (https://www.politifact.com/). Dari sisi masyarakat Fact-Checking adalah rujukan untuk melakukan cek dan recek tentang kebenaran sebuah informasi.

\section{DAFTAR PUSTAKA}

Akurat.com. (2019). Calon PM Inggris Johnson Dipanggil Pengadilan Atas

Hoaks Brexit. Retrieved August 23, 2019, from akurat.co website:

https://akurat.co/ekonomi/id-640121read-calon-pm-inggris-johnson-dipanggilpengadilan-atas-hoaks-brexit

Al-Rodhan, N. (2017, June 7). Post-Truth Politics, the Fifth Estate and the Securitization of Fake News. Global Policy Journal. Retrieved from https://www.globalpolicyjournal.com/blo $\mathrm{g} / 07 / 06 / 2017 /$ post-truth-politics-fifthestate-and-securitization-fake-news

Amalliah. (2018). PERSEPSI

MASYARAKAT TERHADAP FENOMENA HOAKS DI MEDIA ON LINE PADA ERA POST TRUTH. Jurnal AKRAB JUARA, 3(November), 1-15.

Beritasatu. (2018). Lawan Hoaks, NU Luncurkan Channel Pendidikan. Retrieved August 23, 2019, from Beritasatu.com website: https://www.beritasatu.com/nasional/516 806/lawan-hoaks-nu-luncurkan-channelpendidikan

Catholic Herald. (2018). Sharing 'fake news' makes you an accomplice in evil, Pope says. Retrieved August 27, 2019, from 
https://catholicherald.co.uk website: https://catholicherald.co.uk/news/2018/01 /24/sharing-fake-news-makes-you-anaccomplice-in-evil-pope-says/

CNN Indonesia. (2018). Upaya Negara Perangi Penyebaran Berita Palsu. Retrieved August 23, 2019, from cnnindonesia.com website: https://www.cnnindonesia.com/teknologi/ 20180623085115-185-308291/upayanegara-perangi-penyebaran-berita-palsu

CNN Indonesia. (2019). Kapolri Akui Rusuh Manokwari Dipicu Insiden SurabayaMalang. Retrieved August 27, 2019, from https://www.cnnindonesia.com website: https://www.cnnindonesia.com/nasional/2 0190819132804-20-422658/kapolri-akuirusuh-manokwari-dipicu-insidensurabaya-malang

Detik.com. (2018). Wiranto: Ada 53 Kasus Hoaks dan 324 Hate Speech Sepanjang 2018. Retrieved August 23, 2019, from Detik.com website: https://news.detik.com/berita/d4272642/wiranto-ada-53-kasus-hoaksdan-324-hate-speech-sepanjang-2018

Figueira, Á., \& Oliveira, L. (2017). The current state of fake news: Challenges and opportunities. Procedia Computer Science, 121, 817-825. https://doi.org/10.1016/j.procs.2017.11.10 6

Gooch, A. (2017, March). In Pursuit of The Truth. UNO Magazine. Retrieved from https://www.uno-magazine.com/wpcontent/uploads/2017/03/UNO_27_ENG_ alta.pdf

Grech, V. (2017). Fake news and post-truth pronouncements in general and in early human development. Early Human Development, 115(September), 118-120. https://doi.org/10.1016/j.earlhumdev.201 7.09.017

Haryatmoko. (2017, November 15). Ketika Emosi Dominasi Politik. Kompas.Id. Retrieved from https://kompas.id/baca/opini/2017/11/15/ ketika-emosi-dominasi-politik/ Indonesia, P. UU Republik Indonesia No 40 Tahun 2008 Tentang Penghapusan
Diskriminasi Ras dan Etnis. , (2008).

Indonesia, P. UU Republik Indonesia No 7 Tahun 2012 Tentang Penanganan Konflik Sosial. , (2012).

Indonesia, P. UU Republik Indonesia No 19

Tahun 2016 Tentang Perubahan atas UU

No 11 Tahun 2008 Tentang Informasi dan

Transaksi Elektronik., (2016).

Jawapos. (2017). Nahdliyin Harus Tahu, NU

Kini Punya Aplikasi Mobile hingga TV

Channel. Retrieved August 23, 2019,

from Jawapos.com website:

https://www.jawapos.com/nasional/19/11/

2017/nahdliyin-harus-tahu-nu-kini-

punya-aplikasi-mobile-hingga-tv-channel/

Johan Farkas, J. S. (2019). Post-Truth, Fake

News and Democracy (1st ed.). Sweden:

Routledge.

Kapolri. Surat Edaran Kapolri No

SE/6/X/2015. , (2015).

Kompas.com. (2017). Verifikasi Media, Salah Satu Upaya Dewan Pers Lawan "Hoaks." Retrieved August 23, 2019, from

Kompas.com website:

https://nasional.kompas.com/read/2017/0 2/06/08392901/verifikasi.media.salah.sat u.upaya.dewan.pers.lawan.hoaks.?page=a 11

Kompas. (2019, March 13). Lunturnya Kearifan Berpolitik di Era "Post-Truth."

Kompas.Com. Retrieved from https://nasional.kompas.com/read/2019/0 3/13/09014261/lunturnya-kearifanberpolitik-di-era-post-truth?page=all

Liputan6.com. (2018). Basmi Hoaks hingga Akun Palsu, Ini Upaya Facebook Lindungi Pemilu. Retrieved August 23, 2019, from https://www.liputan6.com website:

https://www.liputan6.com/tekno/read/342 4255/basmi-hoaks-hingga-akun-palsu-iniupaya-facebook-lindungi-pemilu

LLORENTE \& CUENCA. (2017). The Post Truth Era: Reality vs. Perception. In $U N O$ Developing Ideas. https://doi.org/10.1145/1165754.1165756

Lusi, S. S. (2019, May 3). Melampaui "PostTruth." Detik.Com. Retrieved from https://news.detik.com/kolom/d4534507/melampaui-post-truth 
Mafindo. (2016). About Mafindo. Retrieved August 23, 2019, from Mafindo.or.id website: https://www.mafindo.or.id/about/ Makassar, T. (2018, November 28). Walubi Sulsel dan Kementerian Kominfo RI Adakan Bincang Digital Tangkal Hoak. Makassar.Tribunnews. Com. Retrieved from https://makassar.tribunnews.com/2018/11 /28/walubi-sulsel-dan-kementeriankominfo-ri-adakan-bincang-digitaltangkal-hoaks

Manser. (1996). Oxford Learner's Pocket Dictionary. Oxford: Oxford University Press.

Mastel. (2017). HASIL SURVEY MASTEL TENTANG WABAH HOAKS NASIONAL. Retrieved from https://mastel.id/hasilsurvey-wabah-hoaks-nasional-2017/

Mirificanews. (2018). Literasi Media Padang Dihadiri Direktur Baru Kominfo. Retrieved August 27, 2019, from http://www.mirifica.net website: http://www.mirifica.net/2018/09/04/litera si-media-padang-dihadiri-direktur-barukominfo/

Parani, R., Pramesuari, A., Maldiva, D. M., \& Felicia, E. (2018). Mempertanyakan Kembali Bhinneka Tunggal Ika Di Era Post Truth Melalui Media Sosial. LONTAR: Jurnal Ilmu Komunikasi, 6(2), 152. https://doi.org/10.30656/lontar.v6i2.953

Pilliang, Y. (2012). MASYARAKAT INFORMASI DAN DIGITAL: Teknologi Informasi dan Perubahan Sosial. Jurnal Sosioteknologi, 11(27), 143-155.

Polri. PERATURAN KEPALA KEPOLISIAN NEGARA REPUBLIK INDONESIA NOMOR 8 TAHUN 2013. , (2013).

Prego, V. (2017, March). Informative Bubbles. UNO-Magazine, 20-21. Retrieved from https://www.uno-magazine.com/wpcontent/uploads/2017/03/UNO_27_ENG_ alta.pdf

Setiawan, I. (2017). Media sosial, politik posttruth, dan tantangan kebangsaan.
Retrieved August 23, 2019, from

http://matatimoer.or.id website:

http://matatimoer.or.id/wp-

content/uploads/2017/09/Media-

sosial.pdf

Sulistyo, E. (2017, November 28). Medsos dan Fenomena "Post-Truth". Koran Sindo.

Retrieved from

https://nasional.sindonews.com/read/1261 141/18/medsos-dan-fenomena-post-truth1511797550

Syahputra, I., \& Ritonga, R. (2019). Citizen Journalism and Public Participation in the Era of New Media in Indonesia: From Street to Tweet. Media and Communication, 7(3), 79. https://doi.org/10.17645/mac.v7i3.2094

Syuhada, K. D. (2018). Etika Media di Era "Post-Truth." Jurnal Komunikasi Indonesia, 6(1), 75-79. https://doi.org/10.7454/jki.v6i1.8789

Tesich, S. (1992, January 2). The Government of Lies. The Nation.

Ulya, U. (2018). Post-Truth, Hoaks, dan Religiusitas di Media Sosial. Fikrah, Vol. 6, p. 283. https://doi.org/10.21043/fikrah.v6i2.4070

Wartaekonomi.co.id. (2018). Hadapi Hoaks di Era Post Truth, Bagaimana Caranya? Retrieved August 23, 2019, from Warta Ekonomi website: https://www.wartaekonomi.co.id/read207 005/hadapi-hoaks-di-era-post-truthbagaimana-caranya.html

Wartaekonomi.co.id. (2019). Kasus Hoaks Meningkat Pesat pada 2019. Retrieved August 23, 2019, from Warta Ekonomi website:

https://www.wartaekonomi.co.id/read233 849/kasus-hoaks-meningkat-pesat-pada2019.html

Zarzalejos, J. A. (2017, March). COMMUNICATION, JOURNALISM AND fact-checking. UNO-Magazine. Retrieved from https://www.unomagazine.com/wpcontent/uploads/2017/03/UNO_27_ENG_ alta.pdf 